\title{
Impact of Macroeconomics Variables on Exports in Indonesia, Philippines, Malaysia and Thailand
}

\author{
Mohammed Y S Alimawi, Lai Wei Sieng* \& Roziana Baharin \\ Faculty of Economics and Management \\ Universiti Kebangsaan Malaysia, Malaysia \\ Email:laiws@ukm.edu.my \\ DOI: https://doi.org/10.37134/jcit.vol10.sp.5.2020
}

Cite this paper (APA): Sieng, L. W., Alimawi, M. Y. S., \& Baharin, R. (2020). Impact of Macroeconomics Variables on Exports in Indonesia, Philippines, Malaysia and Thailand. Journal of Contemporary Issues and Thought, 10, 4657. https://doi.org/10.37134/jcit.vol10.sp.5.2020

\begin{abstract}
Exports play an essential role in the world economy. Therefore, it is important to identify the determinants of exports and it is important for policymakers as increased productivity and international trade are important for each country. This paper examines the determinants of exports in Indonesia, Philippines, Malaysia and Thailand. This study is intended to estimate the impact of import, exchange rate, FDI, inflation and Crude oil on export. Three different econometric techniques such as Levin, Lin and Chu test; also, it has been used three different models for panel data estimation namely Pooled OLS, Random Effect and Fixed Effect. Apart from these techniques, different diagnostic tests have also been applied on the secondary data ranging from 1981-2016 which collected from World Bank. The results of the study show that import and exchange rate are positively and significantly related with export in Indonesia, Philippines, Malaysia and Thailand whereas FDI has a significantly negative effect. To sum up, the study concluded that in order to stimulate exports, governments or policymakers should provide peace and political stability between the four countries and the surrounding region in order to obtain more investors.
\end{abstract}

Keywords: Export; FDI; Import; Inflation; Crude Oil; Exchange Rate

\section{Introduction}

The Association of Southeast Asian Nations (ASEAN) was established in 1967, the members are Indonesia, Singapore, Philippines, Malaysia and Thailand. It was a security organization to ward off the threat of communism that became apparent from communist Vietnam, and later Cambodia and Laos (Bangkok Declaration 1967). However, as Vietnam became entrenched as a communist nation, the focus of ASEAN shifted increasingly towards economic interests. The transformation became formal when the five pioneering members of this association was established to focus more and more firmly on the economic interests of these countries. When ASEAN countries formed a free trade zone with Brunei, the transformation has become official to those countries. Foremost in the arrangement was a vigorous but joint effort to deregulate and streamline tariff procedures among members to stimulate trade and foreign investment. Vietnam, 
Cambodia, Laos and Myanmar subsequently joined to AFTA process. One of the requirements that must be fulfilled by the ASEAN countries is that production costs are low, facilities, human resources skills and good infrastructure, i.e. they are implementing free trade policy (without tariffs) because trade is the basis of support for domestic industries and economic growth. It was important that leading ASEAN members, known as ASEAN-5, to switch from import alternatives to export-oriented as an engine of growth. Singapore continued to export as soon as it left the Malaysian alliance in 1965. Although some countries, especially Malaysia and Indonesia continued to replace imports in heavy industries, the main motive for economic growth in these countries is export-oriented (Drabble, 2004). Indeed, export-processing zones mushroomed in the ASEAN since the 1970s.

Exports can be defined as the sale of goods or services produced in one country to another as international trade. The main concern of export is its benefits to international trade and country as well as its disadvantages and fear that some local industries may be harmed by foreign competition. When a country specializes in producing a particular product and can be produced competitively, these products are available at low prices. External and internal economies are being realized; employment and income levels are expanding and thus making the process of economic development easy. Focusing on export promotion would allow the optimal allocation of global resources. During the 1997-98 financial crises, export revenues did not increase in many East Asian countries. The depreciation of consumption has led to a sharp rise in dollardenominated export prices with only modest increases in export volumes. The absence of a rapid export response to currency depreciation played a crucial role in prolonging the East Asian crisis, such as Malaysia, where the crisis caused a sharp drop in demand for goods and services from major countries (Bank Negara Malaysia). Export growth fell sharply in 2009 to $-10.9 \%$ according to the World Bank (2015).

On the other hand, imports showed a decline in the growth of imports and became the lowest growth of $-18.8 \%$ in 1998. It is expected the export sector should decline with import because the intermediate imported goods are required to use for the production of export. From the perspective of the macroeconomic view, it is shown that there might have a significant effect from inflation, Foreign Direct Investment (FDI) and foreign exchange rate to the export sector. Kabir and Salim (2014) show that the export intensity on 2011 and 2012 in Indonesia, Malaysia, Philippines, Thailand, Singapore and Vietnam are only slightly decreased. This is the impact of the 2008 Global Financial Crisis. The export intensity represents the amount or volume of exports that transacted every year for each dollar of GDP. Cooperation with East Asian countries (China, Japan, and Korea) has increased the export of ASEAN countries and more than one-fifth of ASEAN's total exports flow to three East Asian countries in recent years. Pardede (2011) states that ASEAN has a strong political influence and an important role in international trade.

During the period from 2014 to 2017, there was a good stability in exports in Malaysia, Thailand, Philippines and Indonesia where the proportion of exports in 2014 each country was $73.8,69.3,28.9$, and 23.7 respectively. In 2016, there was a drop in the proportion of exports in Malaysia and Indonesia where the difference between 2016 and 2014 was about 6\% in Malaysia and $4.6 \%$ in Indonesia. In Thailand, there was almost complete stability in the proportion of exports during these years. In Philippines during the first three years in this period, there was a slight decline in exports. Still, in 2017 the ratio increased compared to the first years about $2.5 \%$ 
A better understanding of export changes is vital for Indonesia, Philippines, Malaysia and Thailand economies to continue growth and development. The main objective is to study the relationship between imports, inflation, foreign direct investment, exchange rate and crude oil for export in Indonesia, Philippines, Malaysia and Thailand countries during the period 19812016. Importing materials from countries to countries for local assembly before production for export from one country to another. Is there a relationship between imports and exports? Inflation will cause the currency of these countries to become relatively higher, resulting in higher input and final goods prices. Export exports in these countries will, therefore, fall because of the impact of inflation. Is there a link between inflation and export? Previous studies have shown that foreign direct investment such as finance, materials and machinery in the manufacturing sector will directly lead to higher exports in Malaysia. Otherwise, FDI will make exports increase in Malaysia? According to Marshall Lerner's theory, exports in Malaysia will increase during Malaysian Ringgit Malaysia is consumption. Due to the devaluation of Malaysia, it will cause the export cost to become cheaper in Malaysia. Can Marshall Lerner's theory be used in this study? Is there a relationship between foreign exchange rates in these countries' export direction? Crude oil is a factor that generates huge economic growth for oil-exporting countries. They play an important role in the advantages of global products when it comes to producing goods and services to meet local needs as well as export issues. Does the volatility of crude oil prices affect the growth of the country's exports in view of its important and vital role? It is recognized that assessing the relationship between variables to achieve the goal of creating a strong economy is ultimately necessary for policymakers who make various structural adjustments.

This paper aims to investigate the determinants of exports in Indonesia, Philippines, Malaysia and Thailand using macroeconomic variables: imports, foreign direct investment, exchange rate, inflation and crude oil, and panel data of the countries over the period 1981-2016. The rest of the paper is organized as follows: Section 2 reviews the existing literature on exports and the variable that causes it; Section 3 discusses the methodology and data used. The results and analysis follow next. The paper finishes with the conclusions finally.

\section{Literature Review}

Joshi (2005) defined the export process as the sale of goods and services that would be produced in the home country to other markets in international trade. Most countries may regard exports as the mainstay of their economic growth. Exports directly affect the main source of economic growth linked as part of the production, while indirectly affecting economic growth by facilitating imported services and goods. In order to strengthen the static and dynamic efficiency of economic growth, encouraging and focusing on specialization according to comparative advantage will lead to arise in export. In theory, a rise in the real exchange rate will reduce the domestic currency nominally. In other words, a foreign citizen can buy the local currency because it is cheaper than foreign currency. Domestic goods become more competitive as a result of the devaluation of the local currency.

Consequently, the demand for the product in the local country will increase relatively according to Van Win (2000). The sharp decline in the currencies of the countries suffering from crises will reduce the demand of countries for US exports in the case of the recession in the 
country of crisis. In other words, US imports from these countries are rising as a result of the devaluation of foreign currencies. The Asian crisis was therefore expected to contribute negatively to the growth of the United States through these international trade channels, which caused the inability of the net confrontation in US exports. Melitz and Ottaviano (2008) found evidence that when the currency appreciates, they increase the price of exports in foreign markets and reduce the free export price (FOB) on board because of incomplete transit. This has led to lower FOB export revenues, and therefore less productive exporters have a negative profit that makes them exit the foreign market. In addition, high-performing exporters will increase more dollars but lower exports associated with currency depreciation (Berman et al., 2012). The appreciation of Renminbi (RMB) reduces the probability of export participation (Li et al., 2011). The currency's appreciation is associated with a 1\% drop in China's total exports by $1.89 \%$. (Liu et al., 2014) In Pakistan, the real exchange rate is positively linked to exports, indicating that the real exchange rate increases the export price, leading to increased demand for exports in the market (Kemal and Qadir, 2005). There are also some studies showing that a high exchange rate leading to depreciation of the local currency does not necessarily lead to higher exports in this particular country. According to a study by Zakaria et al. (2012), the exchange rate is one of the factors determining the economic performance of timber exports during the floating system. However, the exchange rate is not only the element that affects the export of timber in Malaysia because the result of the study was minimal. In the United States, the export decision by companies does not find any evidence to determine the relationship between exports and exchange rates (Bernard and Jensen, 2004). In Bangladesh, and the impact of a lower exchange rate may not be inconsistent with all export sub-sectors (Alam, 2010). The relationship may be negative and positive between export and real exchange rate in different export sectors.

Inflations worse off the economy by reducing the purchasing power of income, erosion of living standards as well as uncertainty in life. Most economists believe that rising inflation is likely to be associated with a decline in exports, which has slowed down growth at all levels of income in a huge group of countries. According to Abidin et al. (2013), export determinants can be analyzed using the gravitational model. High inflation in the country will have a negative impact on export activities. In Malaysia, its export to the Organizational of the Islamic Conference (OIC) member country indicates signs of decline as Malaysia's inflation increases because they pointed out that Malaysia's exports to the OIC could be amplified by promoting liberal and more liberal trade policies for the Malaysian economy. Gylfason (1998) studied the relationship between export and determinants that include inflation by statistical methods in cross-sectional data covering 160 countries. He concludes that the decline in exports is due to high inflation, indicating a negative relationship between them. In addition, his study also indicates that the source of primary commodities tends to have higher inflation than manufacturers. According to Dexter et al. (2005), export inflation is positively correlated with each other. However, the analysis shows that the export has a negative result on inflation where the coefficient of all explanatory variables is found to be statistically significant in the short and long term. Furthermore, the test of the causal relationship Granger suggested a bipolar causal relationship between inflation and export. According to the study by Alavinasab (2014), the result of co-integration shows that inflation has a long-run relationship with oil export revenues in Iran and this supports the hypothesis of the study. The study shows that oil export revenues play a dual role in the inflation 
process in the country. When oil export revenues increase, real variables can be improved and will be effective in controlling inflation by reducing overall demand surplus due to the adoption of real variables on oil export revenues. In the Jayathileke and Rathnayake (2013) study, they used the cointegration and causal test to examine the relationship between inflation and economic growth of three Asian countries in the short and long run - China, India and Sri Lanka. Evidence found that Sri Lanka had a significant and inverse relationship between inflation and long-run economic growth. In Kuwait, Saaed (2007) identified a strong negative correlation between GDP and inflation over the long term. Cross-country evidence suggests that high-growth countries tend to have low inflation, while higher inflation has a long-term impact on economic growth (Ahmed and Mortaza, 2005). According to Bruno and Easrerly (1998), the inflation rate of more than $40 \%$ may cause an inverse relationship between inflation and economic growth. By studying 70 countries. Paul et al. (1997) found no evidence in the exits of the relationship between the growth of economy and inflation.

FDI can be an indirect channel to influence GDP through a positive impact on exports (GuruGharana, 2012). According to De Mello (1999) and Chong and Baharumshah (2010), the relationship between exports and FDI is positive. According to Banga (2007), the increase in exports in the country of origin can reduce the uncertainties and risks associated with the inflow of foreign direct investment. The rise in regional trade and investment agreements has increased the likelihood of vertically integrated FDI from abroad to make exports and FDI inflows more integrated. In Vietnam, they found that the significant impact on export behaviour is due to the characteristics of the company, may have significant effects on export behaviour which refer to the current indirect effects based on exports of the domestic company from foreign direct investment. Nguyen and Sun (2012) suggested that through the promotion of export-oriented FDI, the export of domestic firms that indicate a positive relationship may be promoted. In Bulgaria and Romania, Dritsakis (2004) tested that investment cause exports. Stylianon (2014) suggested that FDI could affect two-way economic growth in which investment affects growth by increasing production, employment, and adding value and exports. In order to determine the pattern of FDI and the relationship between FDI, exports and GDP in the United States, he has adopted a time series framework of a vector autoregressive model. This leads to the growth of GDP and exports attracting FDI according to the approach of time series in long run and short run. However, Moran (1998) suggested that the country would be better off not receiving foreign investment at all, in other words, he found that FDI and export had a negative relationship with each other. Countries that insist on foreign investors to meet the requirements of high local content have created high competition for the foreigner. As a result, it shows the negative impact on host countries in terms of growth and export. Study by Wong et al. (2009) tentatively explored the relationship between FDI and service trade in Malaysia and Singapore, as service trade is an important source of growth in these countries. Moreover, both economies are export-oriented and have significant FDI inflows, with Singapore being the largest beneficiary among the countries of South-East Asia. The study examines causal links between inward FDI and country participation in services trade, using two-dimensional and ideal VAR frameworks. The empirical results of Singapore show evidence of the two-way causal relationship between incoming FDI and total trade in services, FDI and import of services (in trivial specifications). This reflects Singapore's relatively open foreign investment policy and the FTA system. For Malaysia, evidence of 
causation is weaker and one-way than foreign direct import FDI. These results are consistent with the various stages of economic development and openness achieved by the two-sample countries and provide a useful background for trade, foreign investment and development strategies.

Imports always increased at a higher pace than the export, thus the current account generates a deficit in the economy. The study was designed to fill the gap in Turkey by examining the longterm relationship between export and import using the methods of joint integration EngleGranger (Celik, 2011). The results showed that the deficit of foreign trade is growing as a result of increased imports and exports. In other words, exports and imports tend to have a positive relationship. Mukhtar and Rasheed (2010) test the long-run relationship between exports and imports in Pakistan analyzed using Johansen Maximum Likelihood cointegration technique. It shows that exports and imports have a long-run relationship, provided that the country violates international budget constraints. Moreover, the use of the vector error correction model (VECM) confirms its stability in the long-run equilibrium relationship between exports and imports as well. It suggests that imports and exports tend to achieve a long-run stable state equilibrium through macroeconomic policies. Based on a study examining the long-term relationship between imports and exports in two Pacific islands, exports and imports were co-integrated into both countries (Narayan and Narayan, 2004). While among exports and imports in Korea, there was a positive co-integrated and a common coefficient on exports (Bahmani-Oskooee and Rhee, 1997). Moreover, the latest study proposed by Arize (2002) found that the co integration between imports and exports in the United States from 1973-1998 had a positive coefficient. However, the relationship between exports and imports in the United States has not found any long evidence and imports and the hypothesis cannot be rejected (Fountas and $\mathrm{Wu}, 1999)$. In other words, there is no evidence from Fountas and $\mathrm{Wu}$ of their relationship between exports and imports.

The price of crude oil plays a sensitive and important role in the global economic process as it is a major resource for industries. The Organization of Petroleum Exporting Countries (OPEC) acts as an important cartel for oil supply in world markets. The Organization controls supply through falling oil prices and, consequently, the global oil market. The impact of high oil prices on the international market cannot be avoided from spreading to the domestic market. May lead Changes in oil prices to changes in the overall price level and thus can affect the export operations and the economy in general. This can increase inflationary pressures and reduce overall monetary and aggregate demand across countries. Consequently, this will have a negative impact on production and thus export will be automatically affected. Several previous studies have shown that increasing oil prices can cause a slowdown in GDP (Husain and Martin, 2015). Dornbusch et al. (2001) also stressed that when volatile oil prices fluctuated, they would have negative repercussions on the economic situation of the country, as oil price shocks would lead to a larger inflationary effect that would translate into lower consumer demand, leading to a downward effect on employment as well as GDP. In addition, volatile oil prices may lead to the lower purchasing power of people, which also means that companies or households will reduce their propensity to invest and consume (Jiranyakul, 2006). On the contrary, Ferderer (1996) argued that fluctuations and oil price changes had a significant positive impact on economic activities. Increased oil prices could benefit oil-exporting countries. This is because high oil prices have become a great opportunity for oil-exporting countries to sell higher prices and have a positive trade balance. 
The increase in the productivity of the State cannot be separated from the availability of factors of production for goods and services produced. This is linked to commodity price fluctuations that play an important role in the production of goods and services. It is alleged that crude oil is one of the most important commodities in the world (Ekmekcioglu, 2012). They noted that crude oil prices were heavily affected by supply and demand. Crude oil has changed the business scenario and created huge economic growth for oil-exporting countries. Crude oil has an important role and many advantages for global products. It is about producing a good or service to meet local needs as well as export issues. Thus, fluctuations in crude oil prices can affect the growth of the country's exports. Given its vital role, the effects of fluctuations in crude oil prices are diverse. Studies conducted after crude oil shocks in the 1970s are a fundamental reason that the crude oil crisis is the cause of the economic recession, especially in the United States and some European countries at that time.

Further empirical studies are being conducted to study the mechanism of oil shocks impact on the economy, from the impact of demand and supply to the impact on trade in goods and services (Hamilton, 2009). The increase in demand for processed crude oil products and the high demand for crude oil has caused oil price volatility and caused uncertainty. Countries with natural resources like crude oil experienced exceptional economic growth due to the large profits from the crude oil trade. The increase in crude oil prices has led to a shift in market scenarios across countries that are constantly looking for an efficient and suitable alternative energy alternative to crude oil alternatives and to meet the needs of producing goods and services, particularly export production in the country (Ekmekcioglu, 2012). Malaysia and Indonesia are known as the two largest oil exporters in Southeast Asia, but there is little research on oil prices and output as studies tend to be more popular among OPEC countries, which will be attractive to the oil price inquiry and link production in other countries. However, Mehrara and Sarem (2009) explained that Indonesia had used real sector diversification to eliminate the adverse effects of oil spills and depression, with results showing little impact on short- and long-term production. This means that this will have a significant impact on the country's exports

\section{Methodology and Data}

The analysis of this study started with simple regression model with six variables from which five independent variables namely import, exchange rate, inflation, foreign direct investment and Crude oil and export is treated as dependent variable. The functional form of the model is:

where

$$
\mathrm{Ex}_{\mathrm{t}}=\beta_{0}+\beta_{1} \mathrm{Im}_{t}+\beta_{2} \mathrm{In}_{\mathrm{t}}+\beta_{3}\left(\mathrm{FDI}_{\mathrm{t}}\right)+\beta_{4}\left(\mathrm{FEX}_{\mathrm{t}}\right)+\beta_{5}\left(\mathrm{OILI}_{\mathrm{t}}\right)+\mu_{\mathrm{t}}
$$

$$
\begin{aligned}
& \text { Ex = Exports } \\
& \text { Im = Imports } \\
& \text { Int = Inflation } \\
& \text { FDI = foreign direct investment } \\
& \text { FEX = exchange rate } \\
& O I L=\text { crude oil }
\end{aligned}
$$


The data is log transformed by taking log of all the variables in the data. Log linearization of the data helps to decrease the chances of expected heteroscedasticity in the data and provides better estimation results. After converting data into log form the model of the study can be represented as

$$
\operatorname{LnEX}_{t}=\beta_{0}+\beta_{1} \operatorname{LnIm}_{t}+\beta_{2} \operatorname{LnIn}_{t}+\beta_{3} \operatorname{LnFDI}_{t}+\beta_{4} \operatorname{LnFEX}_{t}+\beta_{5} \operatorname{LnOILt}_{t}+\varepsilon_{t}
$$

Where, LnEx is the log of Export; LnIm is log of import; LnIn is the log of inflation; LnFDI is log of foreign direct investment; LnFEX is log of exchange rate and LnOIL is log of crude oil. While using a pooled OLS, countries' unobservable individual effects are not controlled therefore heterogeneity of the countries in the analysis can influence the measurements of the estimated parameters (Tiwari and Kalita, 2011). Furthermore, using a panel data model with the incorporation of individual effects has numerous benefits; for example, it allows us to account for individual heterogeneity. Indeed, developing countries differ regarding their colonial history, political regimes, ideologies, and religious affiliations, geographical sites and climatic environments, not to mention a broad range of other country-specific variables. To test the relevance of unobservable individual effects, the Lagrange Multiplier (LM) test could use for that with the null hypothesis of the irrelevance of unobservable individual effects (Mátyás and Sevestre, 2008). Also, there may be a correlation between countries' unobservable effects and growth determinants. If there is no correlation, the most appropriate way of carrying out analysis is using a panel model of random effects. Hausman test is used to test for the possible existence of a correlation.

Panel data analysis is applied in this study. A panel data analysis has the merit of using information concerning cross-section and time-series analyses. It can also take the heterogeneity of each-sectional unit explicitly into account by allowing for individual-specific effects (Davidson and Mackinnon, 2004) and gave more variability, less collinearity among variables, more degrees of freedom and more efficiency (Baltagi, 2001). The four Southeast Asian economies of the current study (Malaysia, Indonesia, Thailand, Philippines) have more or less similarity in culture and geographical proximity, their rapid economic growth during the past two decades. Thus, it is appropriate to pool their four cross-sectional data over a 31-year period (1981-2016) into a panel data set and then use panel data regression to examine the most influential factors to increase export in these countries.

\section{Results and Discussion}

The first step in the econometric analysis is to examine the degree of integration of the variables in equations. Table 1 presents the results of the panel unit-root test to ensure the variables are integrated of the same order based on Levin -Lin-Chu (LLC) test. The results indicate that series are generally stationary at the 1 percent level with intercept. This allows running the regression for Indonesia, Philippines, Malaysia and Thailand. Next, empirical results based on pooled data for Indonesia, Philippines, Malaysia and Thailand countries over the period of 1981-2016 is 
reported in Table 2. Both fixed effect and random effect models are applied. The Hausman test is performed to compare the fixed effects model and the random effects. Hausman test reveals that the fixed effects model is better than the random effects ( $p$-value is less than 0.01). Fixed effect regression shows that Import, crude oil, and exchange rate are vital influences in promoting exports in the ASEAN-4 as a group. As shown in Table 2, the magnitude of the effects of variables is statistically significant.

Table 1: Panel Unit Root Tests for variables in level

\begin{tabular}{lccc}
\hline Variables & Levin, Lin and Chu & $\mathrm{Im}$, Pesaran, and Shin & Final result \\
\hline EX & -4.9859 & -6.5249 & $\mathrm{I}(0)$ \\
& $(0.0000)$ & $(0.0000)$ & $\mathrm{I}(0)$ \\
IN & -3.9548 & -6.0574 & $(0.0000)$ \\
FDI & $(0.0000)$ & -2.9329 & $\mathrm{I}(0)$ \\
IM & -2.4003 & $(0.0017)$ & $\mathrm{I}(0)$ \\
& $(0.0082)$ & -6.4767 & $(0.0000)$ \\
OIL & -4.8460 & -2.0752 & $\mathrm{I}(0)$ \\
& $(0.0000)$ & $(0.0190)$ & $\mathrm{I}(0)$ \\
\hline
\end{tabular}

Source: Authors' calculations using STATA 15.0

Note: Values in parentheses refer to the probability of the test statistics.

Imports show a higher influence on exports. The estimated coefficient for imports is 1.1, which indicates that a $1.0 \%$ percent increase in imports will lead to an increase of $1.1 \%$ in exports. These results are surprising as foreign firms primarily operating in export processing zones have accounted for the bulk of manufactured exports from these countries (Rasiah, 1998; Rasiah et al. 2010). The only concern facing this reality is the lack of technological upgrading to support the structural transformation from low to high value-added activities. Meanwhile, the coefficient of inflation and FDI has the right negative sign and is significant, suggesting its marginal influence. The results provide statistical proof for open economy policies; it also shows that exports from deregulating economies will eventually be stimulated more by other factors. To a large extent, the current study supports those strands of literature supporting the positive influence of imports on export growth. As proved here, the first and foremost determinant of export is the imports.

Table 2: Model Estimation, Random and Fixed Effects

\begin{tabular}{|c|c|c|c|}
\hline Variables & $\begin{array}{c}\text { Pooled } \\
\text { OLS }\end{array}$ & $\begin{array}{c}\text { Random } \\
\text { Effect }\end{array}$ & $\begin{array}{l}\text { Fixed } \\
\text { Effect }\end{array}$ \\
\hline Constant & $\begin{array}{l}-0.37^{* *} \\
(-2.17)\end{array}$ & $\begin{array}{l}-0.37^{* *} \\
(-2.17)\end{array}$ & $\begin{array}{l}-0.42^{* *} \\
(-2.54)\end{array}$ \\
\hline IN & $\begin{array}{c}-0.01 \\
(-1.07)\end{array}$ & $\begin{array}{c}-0.01 \\
(-1.07)\end{array}$ & $\begin{array}{c}-0.01 \\
(-0.10)\end{array}$ \\
\hline FDI & $\begin{array}{l}-0.01 \\
(-1.06)\end{array}$ & $\begin{array}{c}-0.01 \\
(-1.06)\end{array}$ & $\begin{array}{l}-0.03^{* *} \\
(-2.26)\end{array}$ \\
\hline IM & $1.10^{* * *}$ & $1.10^{* * *}$ & $1.05^{* * *}$ \\
\hline
\end{tabular}




\begin{tabular}{|c|c|c|c|}
\hline & $(26.66)$ & $(26.66)$ & $(24.43)$ \\
\hline OIL & $\begin{array}{c}0.04^{* * *} \\
(7.18)\end{array}$ & $\begin{array}{c}0.04^{* * *} \\
(7.18)\end{array}$ & $\begin{array}{c}0.03^{* * *} \\
(3.44)\end{array}$ \\
\hline FEX & $\begin{array}{l}0.01^{* *} \\
(2.10)\end{array}$ & $\begin{array}{l}0.01^{* *} \\
(2.10)\end{array}$ & $\begin{array}{c}0.07^{* * *} \\
(3.63)^{* * * *}\end{array}$ \\
\hline Breusch-Pagan LM test & & & \\
\hline Hausman test & & \multicolumn{2}{|c|}{$\begin{array}{c}18.55 \\
(0.002)^{* * *}\end{array}$} \\
\hline Observations & 132 & 132 & 132 \\
\hline
\end{tabular}

\section{Conclusion}

This paper investigated the determinants of exports in Indonesia, Philippines, Malaysia and Thailand using the data from the period 1981 to 2016. Based on fixed effects model, results show that there is a negative and insignificant relationship between export and foreign direct investment. This study found that export and import are positively and significantly related in Indonesia, Philippines, Malaysia and Thailand countries. The results also reveal that there is a negative and significant relationship between exports and inflation. However, the results showed that there is positively and significantly relationship between export and exchange rate. The study concludes that in order to maximize export gains, policymakers or governments must set interest rates at an appropriate level to attract foreign investors and not harm domestic investors at the same time. These trade liberalization policies that benefit domestic producers and consumers and are effective in attracting foreign direct investment should be pursued. By formulating such policies, it can attract the attention of foreign investors, and the state can enjoy the benefits of foreign direct investment such as increased GDP.

\section{References}

Abidin, I.S.Z., \& Sahlan, R. (2013). The determinants of exports between Malaysia and the OIC member countries: A gravity model approach. Procedia Economics and Finance, 5, 12-19.

Ahmed, S., \& Mortaza, G. (2005). Inflation and economic growth in Bangladesh. Policy Analysis Unit Working Paper Series: WP, 604.

Alam, R. (2010). The Link between real exchange rate and export earning: A cointegration and Granger causality analysis on Bangladesh. International review of Business Research papers, 6(1), 205-214.

Alavinasab, S.M. (2014). Determinants of inflation: The case of Iran. International Journal of Academic Research in Business and Social Sciences, 1(1), 71-77.

Arize, A.C. (2002). Imports and exports in 50 countries: tests of cointegration and structural breaks. International Review of Economics \& Finance, 11(1), 101-115.

Bahmani-Oskooee, M., \& Rhee, H.J. (1997). Are imports and exports of Korea cointegrated?. International Economic Journal, 11(1), 109-114.

Baltagi, B.H. (2001). Econometric analysis of panel data (2nd ed.). New York: John Wiley and Sons.

Banga, R. (2007). Explaining Asian outward FDI. In ARTNeT Consultative Meeting on Trade and Investment Policy Coordination, Bangkok, $16-17$.

Berman, N., Martin, P., \& Mayer, T. (2012). How do different exporters react to exchange rate changes?. The Quarterly Journal of Economics, 127(1), 437-492.

Bernard, A.B., \& Jensen, J.B. (2004). Why some firms export. Review of economics and Statistics, 86(2), 561-569. 
Bruno, M. \& Easrerly, W. (1998). Inflation crisis and long run growth. Journal of Monetary Economics, 41(1), 3-26. Celik, T. (2011). Long Run Relationship between Export and Import: Evidence from Turkey for the period of 19902010. In International Conference on Applied Economics, 119-123.

Choong, C.K., Baharumshah, A.Z., Yusop, Z., \& Habibullah, M.S. (2010). Private capital flows, stock market and economic growth in developed and developing countries: A comparative analysis. Japan and the World Economy, 22(2), 107-117.

Davidson, R., \& MacKinnon, J.G. (2004). Econometric theory and methods (Vol. 5). New York: Oxford University Press.

De Mello, L.R. (1999). Foreign direct investment-led growth: evidence from time series and panel data. Oxford economic papers, 51(1), 133-151.

Dexter, A.S., Levi, M.D., \& Nault, B.R. (2005). International trade and the connection between excess demand and inflation. Review of International Economics, 13(4), 699-708.

Dornbusch, R., Fischer, S., \& Startz, R. (2001). Macroeconomics, (8th Edition). New York: McGraw Hill.

Drabble, J.H. (2004). The economic history of Malaysia. EH.Net Encyclopedia. edited by Robert Whaples. Retrieved from http://eh.net/encyclopedia/economic-history-of-malaysia/

Dritsakis, N. (2004). Tourism as a long-run economic growth factor: an empirical investigation for Greece using causality analysis. Tourism economics, 10(3), 305-316.

Ekmekcioglu, E. (2012). The macroeconomic effects of world crude oil price changes. International Journal of Business and Social Science, 3(6), 268-272.

Ferderer, J.P. (1996). Oil price volatility and the macroeconomy. Journal of macroeconomics, 18(1), 1-26.

Guru-Gharana, K.K. (2012). Econometric investigation of relationships among export, FDI and growth in India: An application of Toda-Yamamoto-Dolado-Lutkephol Granger causality test. The journal of developing areas, 46(2), 231-247.

Gylfason, T. (1998). Output gains from economic stabilization. Journal of Development Economics, 56(1), 81-96.

Hamilton, J.D. (2009). Understanding crude oil prices. The Energy Journal, 30(2), 179-206.

Herwartz, H., \& Plödt, M. (2016). The macroeconomic effects of oil price shocks: Evidence from a statistical identification approach. Journal of International Money and Finance, 61(2), 30-44.

Jayathileke, P.M.B., \& Rathnayake, R.M.K.T. (2013). Testing the link between inflation and economic growth: Evidence from Asia. Modern Economy, 4, 87-92.

Jiranyakul, K. (2006). The Impact of international oil prices on industrial production: the case of Thailand. NIDA Economic Review, 1(2), 35-42.

Joshi, R. (2005). International marketing. New Delhi and New York: Oxford University Press.

Kabir, S., \& Salim, R.A. (2014). Regional economic integration in ASEAN: how far will it go?. Journal of Southeast Asian Economies, 31(2), 313-335.

Kemal, M.A., \& Qadir, U. (2005). Real exchange rate, exports, and imports movements: A trivariate analysis. The Pakistan Development Review, 45, 177-195.

Li, H., Ma, H., andXu, Y. (2011). How do exchange rate movements affect Chinese exports. Retrieved from https://www.bbvaresearch.com/wpcontent/uploads/migrados/WP_0916_tcm348-212762.pdf

Liu, Q., Lu, Y. and Zhou, Y. 2014. Do exports respond to exchange rate changes? Inference from China's Exchange Rate Reform. Retrieved from http://www2.warwick.ac.uk/fac/soc/economics/research/centres/cage/events/conferenc s/trade13/er_disconnect_puzzle_liu.pdf

Mátyás, L. \& Sevestre, P. (2008). The econometrics of panel data: fundamentals and recent developments in theory and practice. Springer Science and Business Media.

Mehrara, M. \& Sarem, M. (2009). Effects of oil price shocks on industrial production: evidence from some oilexporting countries. OPEC Energy review, 33(3), 170-183.

Melitz, M.J. \& Ottaviano, G. (2008). Market Size, Trade, and Productivity. Review of Economic Studies, 75, $295-316$.

Moran, T.H. (1998). Foreign direct investment and development: the new policy agenda for developing countries and economies in transition. Institute of International Economics: Washington DC.

Mukhtar, T., \& Rasheed, S. (2010). Testing long run relationship between exports and imports: Evidence from Pakistan. Journal of Economic Cooperation and Development, 31(1), 41-58.

Narayan, S., \& Narayan, P.K. (2004). Determinants of demand for Fiji's exports: an empirical investigation. The Developing Economies, 42(1), 95-112.

Nguyen, D.T.H., \& Sun, S. (2012). FDI and domestic firms' export behaviour: Evidence from Vietnam. Economic Papers: A journal of applied economics and policy, 31(3), 380-390.

Pardede, S.M. (2011). Towards an economic community: In South East Asia. International Trade Forum, 4, $20-21$. 
Paul, S., Kearney, C., \& Chowdhury, K. (1997). Inflation and economic growth: a multi-country empirical analysis. Applied Economics, 29(10), 1387-1401.

Rasiah, R. (1998). The export manufacturing experience of Indonesia, Malaysia and Thailand: Lessons for Africa. United Nations Conference on Trade and Development.

Rasiah, R., Kaur, K., \& Kumar, A. (2010). Does firm size matter in export, technology, and marketing activities of Indian garment firms?. Asian Journal of Technology Innovation, 18(1), 45-71.

Saaed, A.A. (2007). Inflation and economic growth in Kuwait: 1985-2005-Evidence from co-integration and error correction model. Applied Econometrics and International Development, 7(1), 143-155.

Stilianos, F., \& Jyh-Lin, W. (1999). Are the US current account deficits really sustainable?. International Economic Journal, 13(3), 51-58.

Stylianou, T. (2014). Dynamic relationship between growth, foreign direct investment and exports in the US: an approach with structural breaks. The IUP Journal of Applied Economics, 13(2), 1-15.

Tiwari, A.K., \& Kalita, M. (2011). Governance and foreign aid in ASIAN countries. Economics Bulletin, 31(1), 453465.

Van Win Coop, E., \& Yi, K.M. (2000). Asia crisis postmortem: where did the money go and did the United States benefit?. Economic Policy Review, 6(3), 51-70.

Wong, K.N., Tang, T.C., \& Fausten, D.K. (2009). Foreign direct investment and services trade: Evidence from Malaysia and Singapore. Global Economic Review, 38(3), 265-276.

Zakaria, N.A., Rahim, H.A., \& Merous, N.H. (2012). The impact of exchange rate on Malaysia wood export. International Journal of Business and Technopreneurship, 2(3), 511-520. 